\title{
Effects of soil acidity on Douglas fir seedlings. 1. Rooting characteristics of natural regeneration of Douglas fir in strongly acid forest soils
}

\author{
H. P. Smit ${ }^{1,2}$, N. van Breemen ${ }^{1}$ and W. G. Keltjens ${ }^{2}\left({ }^{1}\right.$ Department of Soil Science \\ and Geology, Wageningen Agricultural University, P.O. Box 37, 6700 AA Wage- \\ ningen, Netherlands; ${ }^{2}$ Department of Soil Science and Plant Nutrition, Wagenin- \\ gen Agricultural University, P.O. Box 8005, 6700 EC Wageningen, Netherlands)
}

Received 8 May 1987; accepted 4 September 1987

\begin{abstract}
The relationship between root development of Douglas fir (Pseudotsuga menziesii) and soil acidity was studied in the field. Correlations suggest that total root length in the mineral soil is affected by high levels of exchangeable aluminium at low levels of exchangeable calcium. However, this was only true if the mineral soil down to $5 \mathrm{~cm}$ depth was extremely acid $\left(\mathrm{pH}\left(\mathrm{H}_{2} \mathrm{O}\right) \leqslant 3.8\right)$. At such low $\mathrm{pH}$, the root length was well correlated with the $\mathrm{Ca} /(\mathrm{Ca}+\mathrm{Al})$ equivalent ratio of the mineral soil at $0-5 \mathrm{~cm}$ depth $(r=0.678 ; P<0.005)$. At higher soil $\mathrm{pH}$, parameters other than exchangeable aluminium and exchangeable calcium seem to be more important in determining total root length.
\end{abstract}

Key words: Douglas fir, root length, soil acidity, aluminium-calcium equivalent ratio.

Introduction. Evidence for a causal relationship between forest die-back and acid atmospheric deposition is increasing (Ulrich, 1983). Important components of the so-called 'acid rain' are $\mathrm{SO}_{2}, \mathrm{NO}_{\mathrm{x}}$ and $\mathrm{NH}_{3}$, which enter the atmosphere through emissions of industry, traffic and intensive animal husbandry. Acid atmospheric deposition, both wet and dry, may directly and indirectly affect forest trees. Direct effects include injury of leaves by gaseous pollutants which may destroy the plant tissue, cuticula and stomata, resulting in nutrient leakage and enhanced transpiration. Indirect effects on forest trees may result from dissolution of inorganic $\mathrm{Al}$ at low $\mathrm{pH}$. Aluminium may become the dominant cation in the soil solution, while concentrations of $\mathrm{Ca}, \mathrm{Mg}, \mathrm{K}$ and $\mathrm{Na}$ are lowered due to leaching. Aluminium may injure roots and may inhibit the uptake of nutrients like $\mathrm{Ca}, \mathrm{Mg}$ and $\mathrm{K}$. Especially when the $\mathrm{N}$ input in the system is high due to deposition of $\mathrm{NO}_{\mathrm{x}}$ and $\mathrm{NH}_{3}$, nutrient deficiencies may appear.

High levels of $\mathrm{Al}$ in the soil solution may affect root length, while Ca may counteract the toxic effect of $\mathrm{Al}$. Effects of $\mathrm{Ca}-\mathrm{Al}$ antagonism on root length of spruce and birch were shown by Rost-Siebert (1985) in experiments involving nutrient so- 
lutions. A negative effect of aluminium on root length of Douglas fir was observed by Ryan et al. (1986a, b). Normally roots of Douglas fir seedlings develop a tap root, and can penetrate the mineral soil up to a depth of $70 \mathrm{~cm}$ (de Hoogh, 1925). Results of previous field work carried out at our laboratory (not published) showed a different rooting pattern of natural regeneration of Douglas fir when grown in forest soils presumably affected by acid deposition. Under these conditions roots were found to grow mainly in the organic surface layer and apparently avoided the mineral soil. A tap root was usually absent.

It was hypothesized that high soil acidity resulted in poor root growth and that root length in the mineral soil decreased with decreasing soil $\mathrm{pH}$ and increasing ratios of exchangeable $\mathrm{Al}$ to exchangeable $\mathrm{Ca}$. To test this hypothesis roots of a number of naturally regenerated Douglas fir seedlings at several stands were studied, and soil samples were analysed for $\mathrm{pH}$, exchangeable $\mathrm{Al}$ and exchangeable $\mathrm{Ca}$. We also took into account other parameters that might influence root growth, such as penetration resistance of the soil, available soil moisture, seedling age, light availability, $\mathrm{Mg}$ and organic matter content of the mineral soil, and the thickness of the litter layer.

Material and methods. From eight stands in five forestry districts in the Netherlands located on the Veluwe and near Staphorst, 40 seedlings 4-7 years old (natural regeneration) were selected at random (five seedlings per stand). The experiment was carried out with naturally regenerated seedlings to avoid mechanical damage to the plant roots caused by transplanting. Moreover, all roots have been developed under natural conditions. The soils involved were Humic Podzols ( 3 stands), Leptic Podzols ( 2 stands), Gleyic Podzols ( 2 stands) and a Dystric Regosol (1 stand). At all plots the soil has been disturbed in the past by digging to a depth of 40 to $80 \mathrm{~cm} \mathrm{ex}$ cept at one of the plots with a Leptic Podzol.

The resistance of the soil near every seedling was measured with a penetrograph and the degree of shading by the mature trees surrounding every seedling was estimated. The age of the seedlings was estimated in the field by counting the number of whorls and subsequently checked in the laboratory by counting the number of annual rings using a dissecting microscope. The plants were uprooted carefully and within a radius of $25 \mathrm{~cm}$ around the stem roots in the litter layer and roots in the mineral soil were sampled separately. At three points at $25 \mathrm{~cm}$ from the plant and with a mutual distance of about $40 \mathrm{~cm}$, soil samples were collected from three depths: the litter layer, $0-5 \mathrm{~cm}$ depth and $5-25 \mathrm{~cm}$ depth. The triplicate samples from the same depths were mixed, freeze-dried and subsequently stored at $5{ }^{\circ} \mathrm{C}$ until analysis. In the mineral soil samples, $\mathrm{pH}\left(\mathrm{H}_{2} \mathrm{O}\right), \mathrm{pH}(\mathrm{KCl})$, organic matter content (loss on ignition) as well as exchangeable ( $1 \mathrm{~mol} / \mathrm{l} \mathrm{KCl}$-extractable $) \mathrm{Al}, \mathrm{Ca}$ and $\mathrm{Mg}$ were determined. Samples from the litter layer were analysed for $\mathrm{pH}\left(\mathrm{H}_{2} \mathrm{O}\right)$ and $\mathrm{pH}(\mathrm{KCl})$ only. The available soil moisture content to a depth of $30 \mathrm{~cm}$ at the beginning of the growing season was estimated from the texture and corrected for the organic matter content (Salter \& Williams, 1969). Total root length of washed roots was estimated with a Comair Root Length Scanner or by the line intersect method. 
Results and discussion. Douglas fir seedlings rooted mainly in the litter layer and in the upper $5 \mathrm{~cm}$ of the mineral soil. Tap roots were usually absent or only rooted shallowly if present. Only in one stand with a Leptic Podzol in loamy parent material relatively deep-rooting seedlings were observed. Total root length varied strongly, from 1 to $30 \mathrm{~m}$.

Penetration resistance down to $80 \mathrm{~cm}$ depth was usually 0.5 to $1.0 \mathrm{MPa}$ and never exceeded values of $1.5 \mathrm{MPa}$, at which difficulties to root growth might be expected. Variation in physical resistance did not explain the variation in tap root length nor in total root length. Total root length in the mineral soil showed a clear significant positive correlation with the $\mathrm{Ca} /(\mathrm{Ca}+\mathrm{Al})$ equivalent ratio at $0-5 \mathrm{~cm}$ depth $(r=$ $0.678 ; P<0.005)$. This correlation, however, was present only if the soil layer at $0-5 \mathrm{~cm}$ depth had a $\mathrm{pH}\left(\mathrm{H}_{2} \mathrm{O}\right)$ below 3.8 (45\% of all observations). The correlation between total root length and the $\mathrm{Ca} /(\mathrm{Ca}+\mathrm{Al})$ equivalent ratio was less if exchangeable $\mathrm{Al}$ and exchangeable $\mathrm{Ca}$ at $5-25 \mathrm{~cm}$ depth were taken into account. This can be explained by the fact that most roots occur just below the litter layer. At $\mathrm{pH}$ values above 3.8 no correlation was observed between total root length and the $\mathrm{Ca} /(\mathrm{Ca}+\mathrm{Al})$ equivalent ratio. These results suggest that low values of $\mathrm{Ca} /(\mathrm{Ca}+$ $\mathrm{Al}$ ) restrict root growth at low $\mathrm{pH}$, whereas at higher $\mathrm{pH}$ levels other factors are more important in determining the total root length.

Together with the $\mathrm{pH}$ of the litter layer and the organic matter content at $0-5 \mathrm{~cm}$ depth the amount of exchangeable $\mathrm{Ca}$ and exchangeable $\mathrm{Al}$ at $0-5 \mathrm{~cm}$ depth predicted about $88 \%$ of the variation in total root length in the mineral soil at low pH levels (Table 1; model 1 ). If exchangeable $\mathrm{Ca}$ and exchangeable $\mathrm{Al}$ at $0-5 \mathrm{~cm}$ were combined to a $\mathrm{Ca} /(\mathrm{Ca}+\mathrm{Al})$ equivalent ratio, about $75 \%$ of the variation in total root length can be explained (Table 1; model 2).

According to this study, reduction of total root length of Douglas fir seedlings caused by high levels of $\mathrm{Al}$ versus low levels of Ca observed in nutrient solution ap-

Table 1. Scheme of statistical analysis.

Total root length (TRL) in the mineral soil. Variation in TRL explained by soil factors if the $\mathrm{pH}\left(\mathrm{H}_{2} \mathrm{O}\right)$ at $0-5$ depth is lower than $3.8(N=18)$.

Model 1 (includes ionic equivalents of $\mathrm{Ca}\left(\mathrm{mmol} \mathrm{kg}^{-1}\right)$ and $\mathrm{Al}(\mathrm{mmol} \mathrm{kg}-1)$ and organic matter (OM) \% at $(0-5 \mathrm{~cm}$ depth and $\mathrm{pH}(\mathrm{KCl})$ of the litter layer)

$\mathrm{TRL}(\mathrm{m})=3.0(\mathrm{Ca})^{* * *}-4.4(\mathrm{Al})^{* * *}+0.1(\mathrm{Al})^{2 * *}+43.1(\mathrm{pH}(\mathrm{KCl}))^{* * *}-2.0(\% \mathrm{OM})-62.3$

explanation of variation $87.9 \%$

significance of the model $P<0.005$

Model 2 (includes $\mathrm{Ca} /(\mathrm{Ca}+\mathrm{Al}$ ) equivalent ratio and the organic matter $(\mathrm{OM}) \%$ at $0-5 \mathrm{~cm}$ depth and $\mathrm{pH}(\mathrm{KCl})$ of the litter layer $)$

$\operatorname{TRL}(\mathrm{m})=101.3(\mathrm{Ca} /(\mathrm{Ca}+\mathrm{Al}))^{* * *}+33.0(\mathrm{pH}(\mathrm{KCl}))^{* * *}-2.3(\% \mathrm{OM})^{*}-84.3$

explanation of variation $75.3 \%$

significance of the model $P<0.005$

${ }^{*} P<0.05 ;{ }^{* *} P<0.005 ;{ }^{* *} P<0.0005$. 
pears to hold also under field conditions. In addition to $\mathrm{Al}$ and $\mathrm{Ca}$, the source of nitrogen $\left(\mathrm{NH}_{4}^{+}\right.$or $\left.\mathrm{NO}_{3}^{-}\right)$may play an important role for growth of plants on acid soils. This problem has not been addressed in the present field study, but is pursued in a subsequent paper (Smit et al., 1987).

Acknowledgement. The authors wish to thank Ir. J. H. Oterdoom of the Dorschkamp Research Institute for Forestry and Landscape Planning for his cooperation and helpful suggestions during this study.

\section{References}

Hoogh, J. de, 1925. Bijdrage tot de kennis van den groei van Pseudotsuga toxifolia Britton in Nederland in verband met zijn beteekenis voor den Nederlandschen bosbouw. Dissertation, Wageningen, 117 pp.

Rost-Siebert, K., 1985. Untersuchungen zur H- und Al-Ionen-toxizität an Keimpflanzen von Fichte ( $P i$ cea abies Karst.) und Buche (Fagus sylvatica L.) in Lösungskultur. Berichte des Forschungszentrums Waldökosysteme/Waldsterben, Göttingen Bd. 12, 219 pp.

Ryan, P. J., S. P. Gessel \& R. J. Zasoski, 1986a. Acid tolerance of Pacific Northwest conifers in solution culture. I. Effect of high aluminium concentration and solution acidity. Plant and Soil 96: 239-257.

Ryan, P. J., S. P. Gessel \& R. J. Zasoski, 1986b. Acid tolerance of Pacific Northwest conifers in solution culture. II. Effect of varying aluminium concentration of constant pH. Plant and Soil 96: 259-272.

Salter, P. J. \& J. B. Williams, 1969. The influence of texture on the moisture characteristics of soil. V. Relationships between particle - size composition and moisture contents at the upper and lower limits of available water. Journal of Soil Science 20: 126-131.

Smit, H. P., W. G. Keltjens \& N. van Breemen, 1987. Effects of soil acidity on Douglas fir seedlings. 2. The role of $\mathrm{pH}$, aluminium concentration and nitrogen nutrition (pot experiment). Netherlands Journal of Agricultural Science 35: 537-540.

Ulrich, B., 1983. Stabilität von Waldökosystemen unter dem Einfluss des 'Sauren Regens'. Algemeine Forstzeitung H.26/27: 670-682.

This synopsis is based on a report 'Invloed van aluminium-toxiciteit op Douglaszaailingen (Pseudotsuga menziesii)' by Harm P. Smit, Departments of Soil Science and Geology and Soil Science and Plant Nutrition, Wageningen Agricultural University, 1986. 212 pp., 63 figs., 45 tables, 73 refs., 5 appendices. Dutch.

Available as paper copy (order R078P, $f 40$ including postage) or microfiches (order R078M, $f 22.50$ including postage) at: NARD, clo Pudoc, P.O. Box 4, 6700 AA Wageningen, Netherlands (telex $45015 \mathrm{blhwg}$ ). 